\title{
Genistein inhibits cell invasion and motility by inducing cell differentiation in murine osteosarcoma cell line LM8
}

Atsushi Nakamura ${ }^{1,2}$, Junichi Aizawa ${ }^{1}, K^{2}$ enshi Sakayama ${ }^{1,3}$, Teruki Kidani ${ }^{1}$, Tomoyo Takata ${ }^{2}$, Yoshiaki Norimatsu², Hiromasa Miura ${ }^{1}$ and Hiroshi Masuno ${ }^{2^{*}}$

\begin{abstract}
Background: One of the problems associated with osteosarcoma is the frequent formation of micrometastases in the lung prior to diagnosis because the development of metastatic lesions often causes a fatal outcome. Therefore, the prevention of pulmonary metastases during the early stage of tumor development is critical for the improvement of the prognosis of osteosarcoma patients. In Japan, soy is consumed in a wide variety of forms, such as miso soup and soy sauce. The purpose of this study is to investigate the effect of genistein, an isoflavone found in soy, on the invasive and motile potential of osteosarcoma cells.
\end{abstract}

Methods: LM8 cells were treated for 3 days with various concentrations of genistein. The effect of genistein on cell proliferation was determined by DNA measurement in the cultures and 5-bromo-2'-deoxyuridine (BrdU) incorporation study. The assays of cell invasion and motility were performed using the cell culture inserts with either matrigel-coated membranes or uncoated membranes in the invasion chambers. The expression and secretion of MMP-2 were determined by immunohistochemistry and gelatin zymography. The subcellular localization and cellular level of $\beta$-catenin were determined by immunofluorescence and Western blot. For examining cell morphology, the ethanol-fixed cells were stained with hematoxylin-eosin (H\&E). The expression of osteocalcin mRNA was determined by reverse transcription-polymerase chain reaction (RT-PCR).

Results: Genistein dose-dependently inhibits cell proliferation. Genistein-treated cells were less invasive and less motile than untreated cells. The expression and secretion of MMP-2 were lower in the genistein-treated cultures than in the untreated cultures. $\beta$-Catenin in untreated cells was located in the cytoplasm and/or nucleus, while in genistein-treated cells it was translocated near to the plasma membrane. The level of $\beta$-catenin was higher in genistein-treated cells than in untreated cells. Treatment of LM8 cells with genistein induced morphological changes, markedly decreased the formation of multilayer masses of cells, and markedly increased the expression of osteocalcin mRNA.

Conclusions: Genistein decreased invasive and motile potential by inducing cell differentiation in LM8 cells. Genistein may be useful as an anti-metastatic drug for osteosarcoma through its differentiation-inducing effects.

Keywords: Genistein, LM8, Cell invasion, Matrix metalloproteinase-2, $\beta$-catenin, Cell differentiation

\footnotetext{
* Correspondence: hmasuno@epu.ac.jp

${ }^{2}$ Department of Medical Technology, Faculty of Health Sciences, Ehime Prefectural University of Health Sciences, Takooda, Tobe-cho, lyo-gun, Ehime, 791-2101, Japan

Full list of author information is available at the end of the article
}

\section{Biomed Central}

(c) 2012 Nakamura et al.; licensee BioMed Central Ltd. This is an Open Access article distributed under the terms of the Creative Commons Attribution License (http://creativecommons.org/licenses/by/2.0), which permits unrestricted use, distribution, and reproduction in any medium, provided the original work is properly cited. 


\section{Background}

Osteosarcoma occurs mainly in the metaphyseal region of the long bones of young people. The most common sites affected are the distal femur, the proximal tibia and the proximal humerus [1,2]. Osteosarcoma grows aggressively at the primary site and often develops micrometastases in the lung prior to diagnosis. The primary treatment of osteosarcoma is the complete removal of tumor by wide excision and aggressive adjuvant chemotherapy [3]. Despite progress in chemotherapy, the development of metastatic tumors in the lung often has a fatal outcome $[2,4,5]$. Therefore, the prevention of pulmonary metastases during the early stage of tumor development is critical for the improvement of the prognosis of osteosarcoma patients.
Metastasis is composed of multiple sequential steps, including cell detachment from the primary tumor, cell motility and invasion, angiogenesis, intravasation into blood, and extravasation into distant organs. A number of factors, such as MMP-2 and vascular endothelial growth factor (VEGF) [6-10], are involved in tumor growth, invasion, and metastasis. An LM8 osteosarcoma cell line with high metastatic potential to the lung was established from murine Dunn osteosarcoma cells, which did not develop pulmonary metastasis when implanted subcutaneously (s.c.) into the backs of $\mathrm{C} 3 \mathrm{H}$ mice [6]. LM8 cells have been used as an excellent tool for studying inhibitory agents against pulmonary metastasis $[7,8]$. Previously, we reported that treatment of nude mice implanted s.c. with LM8 cells into the backs

\section{(A)}

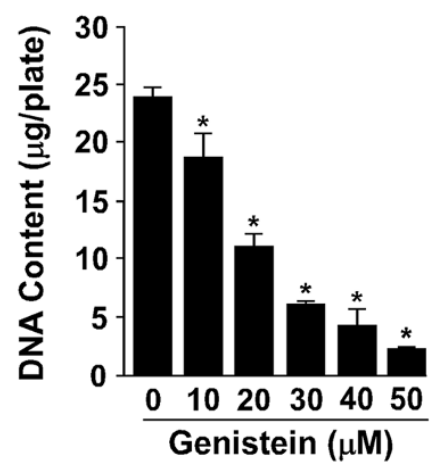

(C) Light microscopy

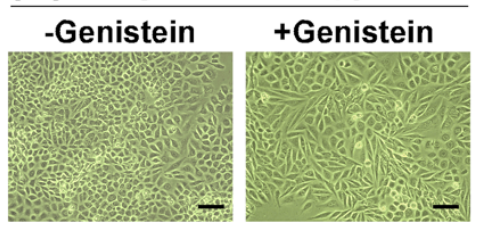

(B)

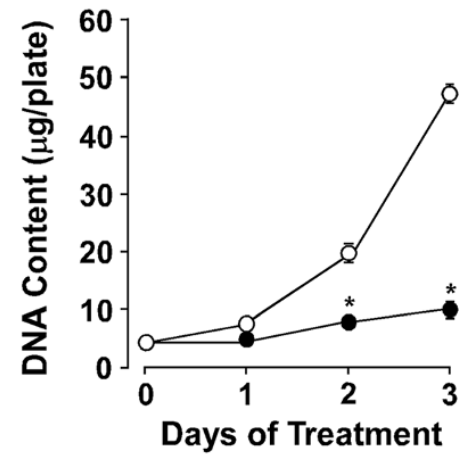

\section{Fluorescent microscopy}

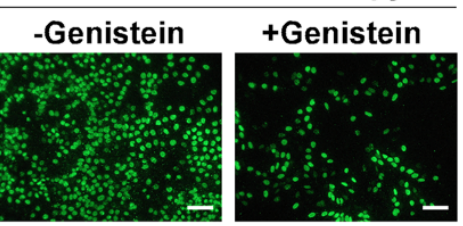

(D)

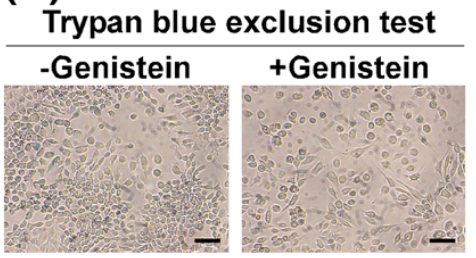

Figure 1 Effect of genistein on cell proliferation and DNA replication. (A) LM8 cells were treated for 3 days with 0-50 $\mu M$ genistein, and the DNA content of the cultures was measured. ${ }^{*} p<0.01$ (compared with the values for the untreated cultures). (B) LM8 cells were treated without (open circle) or with (filled circle) $50 \mu \mathrm{M}$ genistein, the DNA content of the cultures was measured at the indicated intervals. ${ }^{*} p<0.01$ (compared with the values for the untreated cultures). (C) LM8 cells were treated for 3 days without (left panel) or with (right panel) $50 \mu M$ genistein, and immunofluorescence staining of BrdU incorporated into DNA was performed. Both set of images are of the same field of view. Scale bar: $50 \mu \mathrm{m}$. (D) LM8 cells were treated for 3 days without (left panel) or with (right panel) $50 \mu \mathrm{M}$ genistein and stained with trypan blue. Scale bar: $50 \mu \mathrm{m}$. 
with troglitazone, a peroxisome proliferator-activated receptor- $\gamma$ (PPAR $\gamma$ ) ligand, decreased the expression of MMP-2 and VEGF within the primary tumor and inhibited the development of pulmonary metastasis [8].

Soy contains phytoestrogen isoflavones (e.g. genistein, daidzein). In Japan, soy is widely consumed in a wide variety of forms, such as non-fermented foods (dried and green soybeans, tofu, soy milk) and fermented foods (miso, soy sauce). An epidemiological study has shown that consumption of miso soup is inversely associated with the risk of breast cancer [11]. Several experimental studies have shown that genistein inhibits the growth of tumors [12-14]. In the present study, we performed in vitro experiments to analyze the effect of genistein on the growth, invasion, and motility of LM8 cells. Since $\beta$ catenin is associated with tumor cell growth, invasion, motility, and metastasis [15-17], the effect of genistein on the cellular level and subcellular localization of $\beta$ catenin was also examined.

\section{Results \\ Effect of genistein on cell proliferation and DNA replication}

We first evaluated the anti-proliferative effect of genistein against LM8 cells. For this, LM8 cells were treated for 3 days with genistein at the indicated concentrations and the DNA content of the cultures was measured. The untreated cultures (i.e., genistein was absent during the 3-day treatment period) contained $23.9 \mu \mathrm{g} / 35-\mathrm{mm}$ plate of DNA. Genistein dose-dependently decreased the DNA content of the cultures (Figure 1A). Genistein at $50 \mu \mathrm{M}$ decreased the DNA content by $91 \%$. Figure $1 \mathrm{~B}$ shows the time course of the genistein-induced changes in the DNA content. In the untreated and genisteintreated cultures, the DNA content increased during the 3-day treatment period. On day 1, there was no difference in the DNA content between the two cultures. On days 2 and 3, the DNA content of the genistein-treated cultures was significantly lower than that of the untreated cultures.

LM8 cells were incubated with 5-bromo-2'-deoxyuridine (BrdU) during the last $90 \mathrm{~min}$ of the 3-day treatment period to label DNA synthesis (Figure 1C). In the untreated and genistein-treated cultures, positive BrdU immunofluorescence staining was observed in the nucleus. The BrdU-labeling index of the genistein-treated cultures $(32.4 \pm 3.8 \%)$ was significantly $(\mathrm{p}<0.01)$ lower than that of the untreated cultures $(56.4 \pm 3.0 \%)$.

To examine the effect of genistein on cell viability, the trypan blue exclusion test was performed (Figure 1D). In the untreated and genistein-treated cultures, cells that attached to the bottom of the plates excluded trypan blue.
Effect of genistein on subcellular localization and cellular level of $\beta$-catenin

The subcellular localization of $\beta$-catenin was examined by immunofluorescence. In the untreated cultures, positive $\beta$-catenin immunofluorescence staining was observed in the cytoplasm and/or nucleus and was not observed at the plasma membrane (Figure 2A, left panel). In the genistein-treated cultures, positive $\beta$-catenin immunofluorescence staining shifted in localization near to the plasma membrane and was not observed in the nucleus (Figure 2A, right panel).

The cellular level of $\beta$-catenin was examined by Western blot. The intensity of the band corresponding to $\beta$ catenin was stronger in the genistein-treated cultures than in the untreated cultures (Figure 2B), indicating that genistein increased the cellular level of $\beta$-catenin.

Effect of genistein on invasion, motility, MMP-2, and alkaline phosphatase (ALP)

LM8 cells, which had been treated for 3 days without or with $50 \mu \mathrm{M}$ genistein, were harvested by trypsinization, and cell invasion and cell motility assays were performed. When experiments were performed using matrigel-coated membranes, the absorbance of the dye extracted from genistein-treated cells was $24 \%$ of that extracted from untreated cells (Figure 3A). This indicates that genistein-treated cells were less invasive than untreated cells. When experiments were performed using uncoated membranes, the absorbance of the dye extracted from genistein-treated cells was $40 \%$ of that

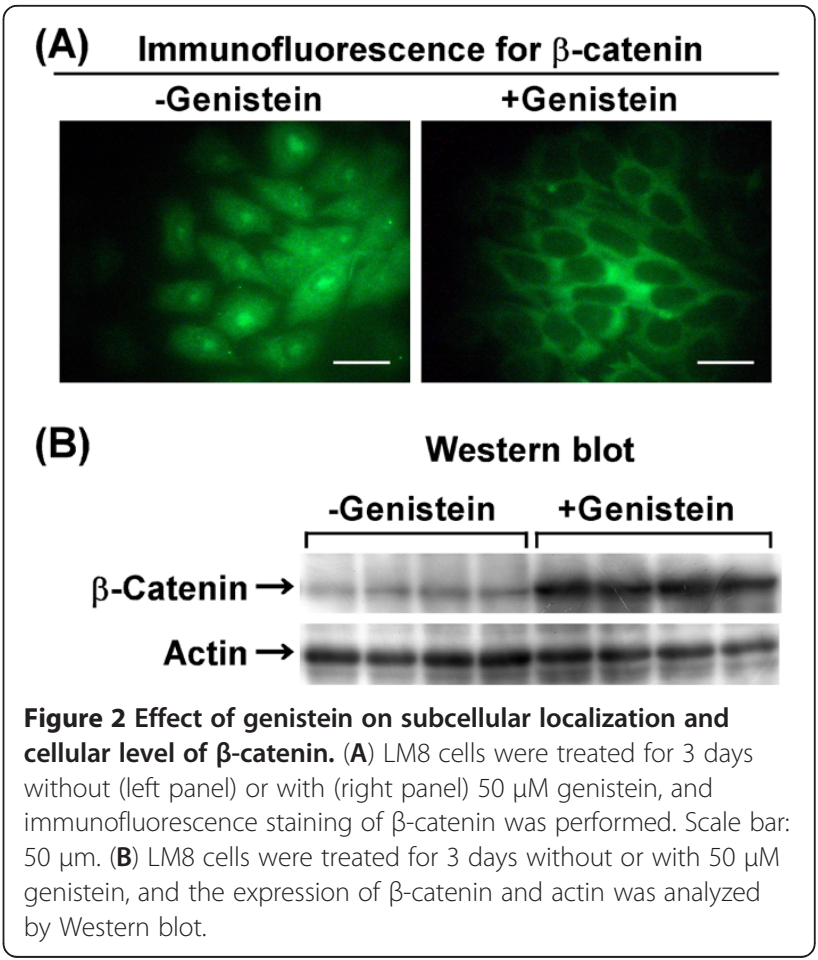




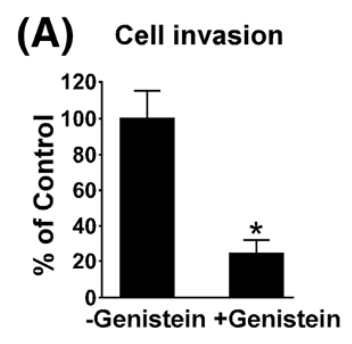

(B) Cell motility

(C)
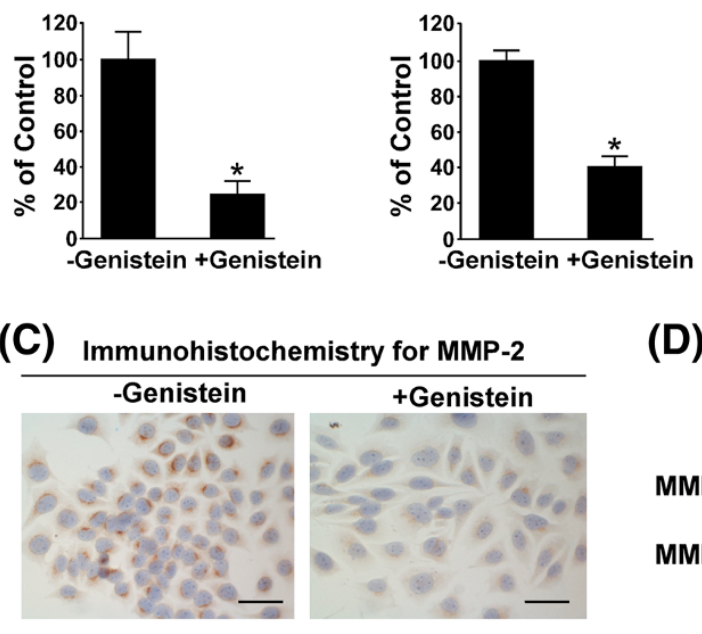

(E)

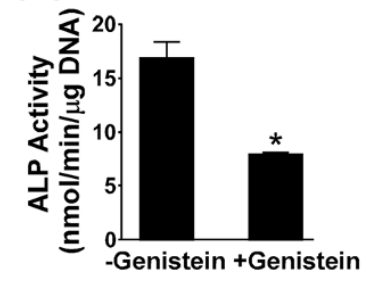

Figure 3 Effect of genistein on invasion, motility, MMP-2, and ALP. (A and B) LM8 cells were treated for 3 days without or with $50 \mu M$ genistein and harvested by trypsinization. Cell invasion and motility assays were performed using either matrigel-coated membranes (A) or uncoated membranes (B). * $p<0.01$ (compared with the values for untreated cells). (C) LM8 cells were treated for 3 days without (left panel) or with (right panel) $50 \mu \mathrm{M}$ genistein, and immunohistochemical staining of MMP-2 was performed. Scale bar: $50 \mu \mathrm{m}$. (D) LM8 cells were treated for 3 days without or with $50 \mu \mathrm{M}$ genistein. The activity of MMP-2 secreted into conditioned media during the last $24 \mathrm{~h}$ of the 3-day treatment was assayed by gelatin zymography. Arrowhead shows the preform of MMP-2. (E) LM8 cells were treated for 2 days without or with $50 \mu M$ genistein, and cellular ALP activity was measured. ${ }^{*} p<0.01$ (compared with the values for untreated cells).

extracted from untreated cells (Figure 3B). This indicates that genistein-treated cells were less motile than untreated cells.

Since MMP-2 degrades type IV collagen, which is present in vascular and subepithelial basement membranes, and plays a pivotal role in cell invasion [9], the expression of MMP-2 was examined by immunohistochemical staining (Figure 3C). In both untreated and genistein-treated cells, positive MMP-2 immunostaining was observed in the cytoplasm. The intensity of immunostaining was weaker in genistein-treated cells than in untreated cells, thus indicating that genistein-treated cells expressed less MMP-2 than untreated cells.

The activity of MMP-2 secreted into conditioned media during the last $24 \mathrm{~h}$ of the 3-day treatment period was assayed by gelatin zymography (Figure 3D). MMP-2 was secreted from both untreated and genistein-treated cells; however, the activity of MMP-2 secreted from genisteintreated cells was lower than that secreted from untreated cells. Low MMP-9 activity was detected in conditioned media from untreated cells, but not genistein-treated cells.
The ALP activity in LM8 cells is higher than that in Dunn cells [6], suggesting that the ALP activity in osteosarcoma cells may be associated with metastatic potential. We treated LM8 cells without or with $50 \mu \mathrm{M}$ genistein for 2 days and measured cellular ALP activity (Figure 3E). The ALP activity in genistein-treated cells $(7.9 \pm 0.2 \mathrm{nmol} /$ $\mathrm{min} / \mu \mathrm{g}$ DNA) was significantly lower than that in untreated cells $(16.9 \pm 1.5 \mathrm{nmol} / \mathrm{min} / \mu \mathrm{g}$ DNA).

\section{Does genistein induce the differentiation of LM8 cells?}

We stained ethanol-fixed LM8 cells with hematoxylineosin (H\&E) and observed cell morphology. In the untreated cultures, the majority of cells $(92.0 \pm 2.0 \%)$ were cuboidal in shape with filopodial and lamellipodial structures surrounding the cell surface (Figure 4A, left panel). These cells grew to form numerous multilayer masses even at low cell density (in ellipse in Figure 4A). The genistein-treated cultures contained two morphologically different cell types; one was cuboidal in shape and the other was spindle-shaped, which became more flattened with clear cell-cell margins (Figure 4A, right panel). The 


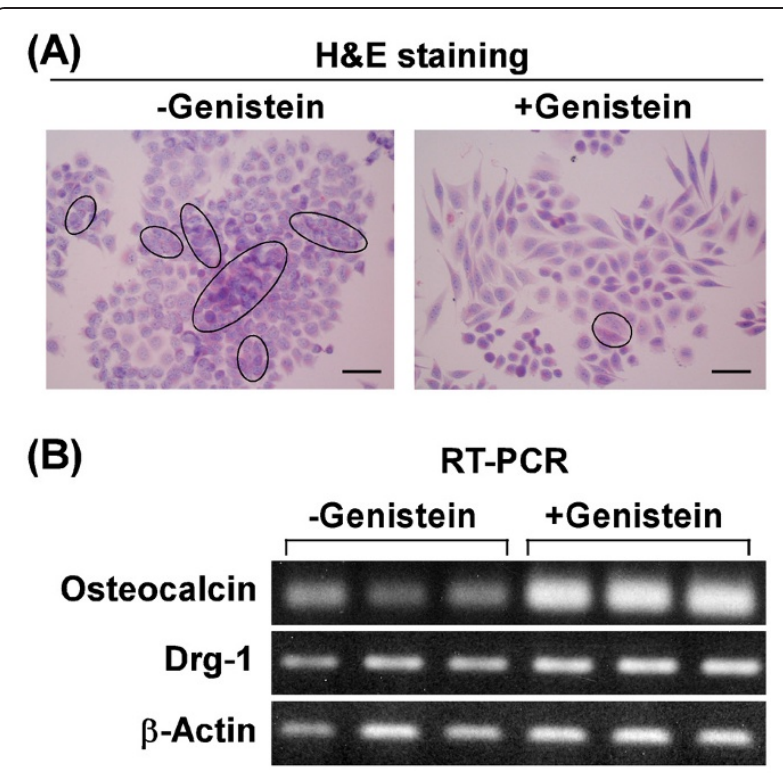

\section{(C) Immunohistochemistry for Drg-1}

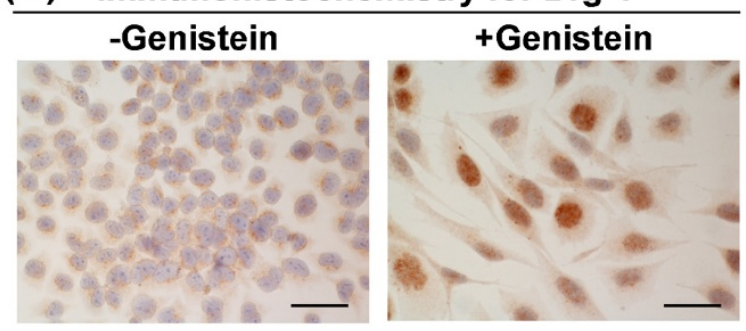

Figure 4 Effect of genistein on differentiation of LM8 cells. (A) LM8 cells were treated for 3 days without (left panel) or with (right panel) $50 \mu \mathrm{M}$ genistein, fixed with ethanol, and stained with H\&E. Scale bar: 50 Hm. (B) LM8 cells were treated for 3 days without or with $50 \mu \mathrm{M}$ genistein, and the expression of mRNAs of osteocalcin, Drg-1, and $\beta$-actin was examined by RT-PCR. (C) LM8 cells were treated for 3 days without (left panel) or with (right panel) $50 \mu \mathrm{M}$ genistein, and immunohistochemical staining of Drg-1 was performed. Scale bar: $50 \mu \mathrm{m}$.

ratio of the number of spindle-shaped cells to the total number of cells was $46.4 \pm 2.9 \%$. Multilayered cells were markedly decreased in the genistein-treated cultures. These findings suggest that genistein may induce the differentiation of LM8 cells.

To confirm this, we examined the expression of mRNAs of osteocalcin, which is a marker of mature osteoblasts [18], and differentiation-related gene-1 (Drg-1), which is associated with the induction of differentiation in tumors [19], by reverse transcription-polymerase chain reaction (RT-PCR) (Figure 4B). Untreated cells expressed a low level of osteocalcin mRNA, while genistein-treated cells expressed a markedly high level of osteocalcin mRNA. Untreated cells expressed a significant level of Drg-1 mRNA. The level of Drg-1 mRNA in genistein-treated cells was similar to that in untreated cells.
The subcellular localization of Drg-1 was examined by immunohistochemical staining. In untreated cells, positive Drg-1 immunostaining was observed in the cytoplasm (Figure 4C, left panel), while in genistein-treated cells, it was mostly observed in the nucleus (Figure $4 \mathrm{C}$, right panel).

\section{Discussion}

Since genistein has been reported to inhibit tumor growth [12-14], we first examined the effect of genistein on the proliferation of LM8 cells. The results of BrdU incorporation into DNA and DNA measurement revealed that genistein inhibited DNA replication and cell proliferation in cultures of LM8 cells (Figure 1A and $1 \mathrm{C})$. Of course, there is concern that this inhibition could be due to a cytotoxic effect of genistein on LM8 cells. However, this does not appear to be the case because cells did not detach from the bottom of the plates during the 3-day treatment period. Moreover, the results of the trypan blue exclusion test showed that genisteintreated cells that attached to the bottom of the plates were viable cells (Figure 1D). Genistein at a higher concentration $(100 \mu \mathrm{M})$ also inhibited the proliferation of LM8 cells without affecting cell viability (data not shown). These findings indicate that genistein-induced inhibition of cell proliferation was not due to a cytotoxic effect. There are reports on the effect of genistein on the proliferation of normal cells. In cultures of 3T3-L1 fibroblasts, genistein at 50 and $100 \mu \mathrm{M}$ inhibits cell proliferation [20]. In cultures of endothelial cells, genistein at lower concentrations (0.001-10 nM) stimulates cell proliferation, while at a higher concentration $(1 \mu \mathrm{M})$ this chemical inhibits it [21].

When LM8 cells are implanted s.c. into the backs of mice, a $100 \%$ pulmonary metastatic rate is observed within 4 weeks [6-8]. The initial step of metastasis is cell detachment from the primary tumor. Since $\beta$-catenin is essential for cadherin-mediated cell-cell adhesion, reduced expression of $\beta$-catenin and cadherins at the cell surface is associated with tumor metastasis [22,23]. Loss of membranous $\beta$-catenin occurs commonly in primary colorectal cancers with metastatic potential and in the corresponding colorectal liver metastases [23]. Our results of immunofluorescence showed loss of membranous $\beta$-catenin in LM8 cells (Figure 2A, left panel), indicating that cell-cell adhesiveness may be reduced in LM8 cells.

Genistein affects the subcellular localization and expression level of $\beta$-catenin in normal cells. For example, treatment of mouse $\mathrm{HC} 11$ mammary epithelial cells with genistein increases membranous $\beta$-catenin [24]. In mammary glands of young female rats fed a genisteincontaining diet, $\beta$-catenin is predominantly localized to ductal epithelial cell membranes [25] and the level of 
this protein is higher compared with those fed a control diet [24]. Therefore, we examined whether genistein affects the subcellular localization and cellular level of $\beta$-catenin in LM8 cells. In genistein-treated cells, immunofluorescence staining of $\beta$-catenin was observed near the plasma membrane (Figure 2A, right panel). The results of Western blot showed that genisteintreated cells contained higher levels of $\beta$-catenin than untreated cells (Figure 2B). These findings suggest that genistein may promote intracellular adhesion of LM8 cells. This is the first report to focus on the subcellular localization and cellular level of $\beta$-catenin following genistein treatment in osteosarcoma cells.

The next step of metastasis is invasion of tumor cells into basement membranes, which involves distinct events, such as cell motility and MMP expression. Invasive tumors exhibit active migration and high levels of MMPs [9]. LM8 cells have been reported to exhibit higher invasive potential, higher MMP-2 activity, and higher ALP activity than Dunn cells with no metastatic potential [6]. In patients with osteosarcoma, high levels of ALP activity in serum are associated with a poor clinical outcome [3]. In the present study, we found that genistein-treated cells were less invasive and less motile (Figure 3A and 3B), exhibited lower expression and secretion of MMP-2 (Figure 3C and 3D), and exhibited lower ALP activity (Figure 3E) compared with untreated cells. Taken together, our findings suggest that genisteintreated cells might lose metastatic potential.

When $\beta$-catenin is translocated to the nucleus, it activates target genes, such as cyclin D1 and c-myc, and promotes the growth of tumor cells [15,26,27]. In intestinal-type gastric cancer, $\beta$-catenin in the nucleus not only plays a role in early tumor growth, but it also functions in initiation of invasive processes [27]. In osteosarcoma that has metastasized to the lung, $\beta$ catenin is detected in the cytoplasm and/or nucleus, whereas in primary osteosarcoma that has not metastasized for more than five years, it is not detected in the cytoplasm and/or nucleus [16], indicating that the presence of $\beta$-catenin in the cytoplasm and/or nucleus is a marker of metastatic potential of osteosarcoma to the lung. Our results of immunofluorescence showed that $\beta$-catenin was present in the cytoplasm and/or nucleus of LM8 cells (Figure 2A, left panel) and that after treatment of LM8 cells with genistein, $\beta$-catenin was translocated near to the plasma membrane and was not found in the nucleus (Figure 2A, right panel). This translocation of $\beta$-catenin may result in decreases in proliferative rate and invasive potential of genisteintreated cells. A similar translocation of $\beta$-catenin from the nucleus to the plasma membrane has been reported in human HT-29 colon cancer cells treated with thiazolidinedione, a PPAR $\gamma$ ligand [17].
Treatment of LM8 cells with genistein induced morphological changes (Figure 4A) and markedly increased the level of osteocalcin mRNA (Figure 4B). Moreover, this treatment markedly decreased the formation of multilayer masses (Figure 4A), suggesting that genisteintreated cells grew with contact inhibition. Contact inhibition is a characteristic of normal cells grown on plastic culture plates, which is lost in cancerous cells [28]. On the basis of these findings, we concluded that genistein induced the differentiation of LM8 cells. There are a few reports on the association of genistein with cell differentiation. Treatment of mouse B16 melanoma cells with genistein induces morphological changes characteristic of differentiation, such as enlargement of the soma and nuclei together with the formation of dendritic-like structures [12]. Treatment of human MG 63 osteosarcoma osteoblasts with genistein increases the level of collagen and stimulates the formation of calcification foci [13].

Drg-1 is expressed at lower levels in tumors than in normal tissue [19,29]. Overexpression of Drg-1 gene in human SW620 metastatic colon cancer cells induces morphological changes that are similar to differentiation-specific changes induced by known differentiation reagents such as tributyrin and a ligand of retinoid X receptor LG268 [30], thus indicating that Drg-1 plays a role in differentiation of tumor cells. However, there is a contradictory report on the involvement of Drg-1 in cell differentiation. Human hepatocellular carcinomas express a higher level of Drg-1 than non-tumor liver or cirrhotic and benign liver lesions [31]. Moreover, hepatocellular carcinomas that are moderately and poorly differentiated express a higher level of Drg-1 than those that are well differentiated [31]. The positive or negative association of Drg1 with cell differentiation depends on tumor types. Therefore, we examined the effect of genistein on the expression of Drg-1 mRNA by RT-PCR. LM8 cells significantly expressed Drg-1 mRNA. Genistein did not increase the expression of Drg-1 mRNA in LM8 cells (Figure 4B). Thus, the expression of Drg-1 in LM8 cells appears not to be associated with the induction of cell differentiation.

Drg-1 is located in the cytoplasm of human EJ bladder carcinoma cells [29], human hepatocellular carcinoma cells [31], and human prostate cancer cells [32]. Our results of immunohistochemical staining also reveal that Drg-1 in LM8 cells was located in the cytoplasm (Figure 4C, left panel). After treatment of LM8 cells with genistein, Drg-1 mostly shifted in localization from the cytoplasm to the nucleus (Figure $4 \mathrm{C}$, right panel). A study with human U2OS osteosarcoma cells expressing Drg-1 small interfering RNA showed that Drg-1 is associated with the production of osteocalcin [33]. Taken 
together, our findings suggest that Drg- 1 in the nucleus of genistein-treated cells may play a role in the expression of osteocalcin mRNA.

In postmenopausal Japanese women [11] and AsianAmerican women [34], the risk of breast cancer is inversely associated with isoflavone intake during adult life. Asian-American women who are high consumers of isoflavone $(>12.68 \mathrm{mg} / 1,000 \mathrm{kcal})$ show a significantly reduced risk of breast cancer compared with those who are low consumers $(\leq 1.79 \mathrm{mg} / 1,000 \mathrm{kcal})$ [34]. However, isoflavones at the levels commonly consumed by nonAsian US women (an average intake equivalent to less than one serving of tofu per week) have little effect on breast cancer risk [35]. In mice implanted with human 253J B-V bladder cancer cells, dietary genistin $(0.14 \%$ of the diet), the natural form of genistein in soy, inhibits tumor growth at the primary site and pulmonary metastasis [14]. In mice implanted with human PC3-M prostate cancer cells, dietary genistein $(100$ and $250 \mathrm{mg} / \mathrm{kg}$ diet) inhibits pulmonary metastasis without affecting tumor growth at the primary site [36].

\section{Conclusions}

Genistein induced cell differentiation and translocated $\beta$-catenin near to the plasma membrane, resulting in lowering of the proliferative rate and invasive potential of LM8 cells. Genistein may be useful as an anti-metastatic drug for osteosarcoma through its differentiationinducing effects.

\section{Methods}

\section{Cell culture}

Genistein (Sigma-Aldrich, St. Louis, MO) was dissolved in dimethyl sulfoxide. LM8 cells (RBRC-RCB1450; Riken BRC Cell Bank, Ibaraki, Japan) at a concentration of $1.25 \times 10^{3}$ cells $/ \mathrm{cm}^{2}$ were seeded on a $35 \mathrm{~mm}$ plate in the culture medium, which contained $10 \%$ fetal bovine serum (FBS), 100 units $/ \mathrm{ml}$ penicillin, and $100 \mu \mathrm{g} / \mathrm{ml}$ streptomycin in Dulbecco's modified Eagle's medium (DMEM). After $24 \mathrm{~h}$ of seeding, the medium was replaced with culture medium containing genistein at the indicated concentrations. Then, cells were incubated for 1-3 days.

For trypan blue exclusion test, cells were treated for 3 days without or with $50 \mu \mathrm{M}$ genistein, washed twice with phosphate-buffered saline (PBS), stained for $1 \mathrm{~min}$ with $0.25 \%$ trypan blue in PBS, and washed 3 times with PBS for phase-contrast microscopy analysis (magnification: $\times 100$ ).

\section{Measurements of DNA and ALP activity}

For DNA measurement, cells were treated for 1-3 days without or with genistein $(10-50 \mu \mathrm{M})$, harvested in $0.3 \mathrm{ml}$ of solution A $(10 \mathrm{mM}$ Tris, $0.1 \%$ Triton X-100, $\mathrm{pH}$ 7.5), sonicated briefly at $0^{\circ} \mathrm{C}$, and centrifuged. DNA in the supernatant was measured fluorometrically by the method of Hinegardner [37] using calf thymus DNA as a standard. For measurement of ALP activity, cells were treated for 2 days without or with $50 \mu \mathrm{M}$ genistein. The ALP activity in the supernatant of cell homogenate was measured using a kit for ALP (Alkaline phospha B-test; Wako Pure Chemical Industries Ltd., Osaka, Japan) according to the manufacturer's instructions. The results are expressed as the means \pm SD of four plates.

\section{Cell invasion and motility assays}

Cell invasion and motility were determined using the cell culture inserts with either matrigel-coated membranes ( 6 wells, $8 \mu \mathrm{m}$ pore size; BD Biosciences, Franklin Lake, NJ) or uncoated membranes (12 wells, $8 \mu \mathrm{m}$ pore size; BD Biosciences) in the invasion chambers as described previously [8]. Briefly, the chambers were assembled using the inserts with either matrigel-coated membranes or uncoated membranes and DMEM containing $10 \%$ FBS as a chemoattractant in the lower compartment. LM8 cells, which had been treated without or with $50 \mu \mathrm{M}$ genistein for 3 days, were harvested by trypsinization, and suspended in DMEM containing 0.1\% bovine serum albumin (BSA). The cells $\left(5 \times 10^{5}\right.$ cells $/ 2$ $\mathrm{ml}$ for invasion assay or $2.5 \times 10^{5}$ cells $/ \mathrm{ml}$ for motility assay) were added to the inserts. The assembled chambers were incubated for $48 \mathrm{~h}$ or $24 \mathrm{~h}$ at $37^{\circ} \mathrm{C}$. After removal of non-migrating cells on the upper surface of the membrane by wiping with a cotton swab, the cells on the bottom surface of the membrane were fixed with $100 \%$ ethanol for $30 \mathrm{sec}$ and stained with toluidine blue for $10 \mathrm{~min}$. The membrane was washed with ethanol and dried. The dye was dissolved with $10 \%$ acetic acid and quantitated by measuring the absorbance at $590 \mathrm{~nm}$. The results are expressed as the means \pm SD for six membranes.

\section{Immunofluorescence and immunohistochemical staining} LM8 cells $\left(1.19 \times 10^{3}\right.$ cells $\left./ \mathrm{cm}^{2}\right)$ were incubated for $24 \mathrm{~h}$ on a 2-well chamber slide (Nalge Nunc International, Osaka, Japan). Then, cells were treated for 3 days without or with $50 \mu \mathrm{M}$ genistein. The cells were incubated with $30 \mu \mathrm{M}$ BrdU (Wako Pure Chemical Industries) during the last $90 \mathrm{~min}$ of the 3-day treatment period, fixed in $70 \%$ ethanol for $30 \mathrm{~min}$, incubated in $100 \%$ ethanol for $10 \mathrm{~min}$, treated with $1.5 \mathrm{~N} \mathrm{HCl}$ for $30 \mathrm{~min}$, and blocked with $0.5 \%$ Tween 20 for 5 min. Thereafter, cells were incubated for $1 \mathrm{~h}$ with a mouse monoclonal antiBrdU antibody (1:15 dilution; Dako Japan, Inc., Tokyo, Japan) followed by 1-h incubation with a fluorescein isothiocyanate (FITC)-labeled anti-mouse IgG (1:20 dilution; Zymed Laboratories, Inc., San Francisco, CA) in the dark. Cells were then mounted in fluorescence mounting medium (Dako Japan) for fluorescent 
microscopy analysis (magnification: $\times 100$ ). Five fields of the culture were randomly photographed. The BrdUlabeling index was calculated by dividing the number of BrdU-positive cells by the total number of cells (170-795 cells/a field). The results are expressed as the mean \pm SD for five determinations. The antibodies used for immunofluorescence and immunohistochemical staining were diluted with PBS containing 1\% BSA.

For immunofluorescence staining of $\beta$-catenin, cells were treated for 3 days without or with $50 \mu \mathrm{M}$ genistein, fixed with ethanol as described above, and incubated for $1 \mathrm{~h}$ with a rabbit polyclonal antibody to $\beta$-catenin (1:15 dilution; Santa Cruz Biotechnology, Inc., Santa Cruz, CA) followed by 1-h incubation with an FITC-labeled antirabbit IgG (1:20 dilution; Santa Cruz Biotechnology) in the dark. Cells were then mounted in fluorescence mounting medium for fluorescent microscopy analysis (magnification: $\times 400)$. For immunohistochemical staining of MMP-2 and Drg-1, the ethanol-fixed cells were incubated for $1 \mathrm{~h}$ with rabbit polyclonal antibodies to either MMP-2 or Drg-1 (1:15 dilution; Santa Cruz Biotechnology) followed by 1-h incubation with horseradish peroxidase (HRP)-conjugated ENVISION+ (Dako Japan). The positive cells were visualized by adding diaminobenthidine (DAB; Dako Japan). The nuclei were counterstained with hematoxylin. Cells were then mounted in glycergel (Dako Japan) for light microscopy analysis (magnification: $x$ 400).

\section{H\&E staining}

LM8 cells were treated for 3 days without or with $50 \mu \mathrm{M}$ genistein, fixed with ethanol as described above, and stained with H\&E. Cells were then mounted in glycergel for light microscopy analysis (magnification: $\times 200$ ). Five fields of the culture were randomly photographed. The ratio of the number of spindle-shaped cells to the total number of cells (102-156 cells/a field) was estimated, with the exception of multilayered cells. The results are expressed as the mean $\pm \mathrm{SD}$ for five determinations.

\section{Western blot analysis}

LM8 cells $\left(1.25 \times 10^{3}\right.$ cells $\left./ \mathrm{cm}^{2}\right)$ were incubated for $24 \mathrm{~h}$ on a $60 \mathrm{~mm}$ plate. Then, cells were treated for 3 days without or with $50 \mu \mathrm{M}$ genistein, harvested in $0.6 \mathrm{ml}$ of solution A containing a protease inhibitor cocktail (1:100 dilution; Calbiochem-Novabiochem Co., La Jalla, CA), sonicated briefly at $0^{\circ} \mathrm{C}$, and centrifuged. The same amount of supernatant protein $(16.5 \mu \mathrm{g} / \mathrm{lane})$ was separated by sodium dodecyl sulphate-polyacrylamide gel electrophoresis (SDS-PAGE, 7.5\% acrylamide gel) and transferred onto a PVDF membrane (GE Healthcare UK Ltd. Buckinghamshire HP7 9NA, England). The membrane was incubated for $1 \mathrm{~h}$ with rabbit polyclonal antibodies to either $\beta$-catenin or actin (1:2,000 dilution; Santa
Cruz Biotechnology) followed by 1-h incubation with a HRP-conjugated anti-rabbit IgG (1:25,000 dilution; GE Healthcare). Blots were visualized using the ECL Advance Western Blotting Detection Kit (GE Healthcare) according to the manufacturer's instructions. The experiment was performed using four independent samples for each treatment.

\section{Assay of MMP-2 by gelatin zymography}

LM8 cells were treated for 2 days without or with $50 \mu \mathrm{M}$ genistein, washed 3 times with PBS, and incubated with FBS-free DMEM for $1 \mathrm{~h}$. The medium was then replaced with FBS-free DMEM without or with $50 \mu \mathrm{M}$ genistein, and the cells were incubated for $24 \mathrm{~h}$. The conditioned media were filtered through $0.2 \mu \mathrm{m}$ filters. The activity of MMP-2 in conditioned media was assayed by gelatin zymography as described previously [8]. The experiment was performed using four independent samples for each treatment.

\section{Total RNA isolation and RT-PCR}

Total RNA was isolated from a $60 \mathrm{~mm}$ plate using a GenElute Mammalian Total RNA Kit (Sigma-Aldrich) according to the manufacturer's instructions. Total RNA $(1 \mu \mathrm{g})$ was treated with DNase I (Sigma-Aldrich) and then reverse-transcribed using the Transcriptor First Strand cDNA Synthesis Kit (Roche, Indianapolis, IN) according to the manufacturer's instructions. $1 \mu \mathrm{l}$ of cDNA was subjected to PCR in a final volume of $25 \mu \mathrm{l}$ containing $1 \times$ PrimeSTAR $^{\mathrm{ma}}$ reaction buffer, $0.2 \mathrm{mM}$ dNTPs, $1 \mathrm{mM} \mathrm{MgCl}$, $0.4 \mu \mathrm{M}$ of each primer, and 0.625 U of PrimeSTAR ${ }^{\text {tw }}$ HS DNA Polymerase (Takara Bio Inc., Otsu, Japan). The primers for mouse osteocalcin [38], mouse Drg-1 (from NCBI/Primer-BLAST), and mouse $\beta$-actin [39] are listed in Table 1 . The PCR condition was as follows: $10 \mathrm{sec}$ at $98^{\circ} \mathrm{C}$ (denaturation), $10 \mathrm{sec}$ at $56^{\circ} \mathrm{C}$ (annealing), and $30 \mathrm{sec}$ at $72^{\circ} \mathrm{C}$ (extension) for osteocalcin and $\beta$-actin; $10 \mathrm{sec}$ at $98^{\circ} \mathrm{C}, 10 \mathrm{sec}$ at $60^{\circ} \mathrm{C}$, and $30 \mathrm{sec}$ at $72^{\circ} \mathrm{C}$ for Drg-1. The PCR products were separated on $2 \%$ agarose gels and visualized by ethidium

\section{Table 1 Primers used for RT-PCR analysis}

\begin{tabular}{|c|c|c|c|}
\hline & Primers & Product (bp) & Cycles \\
\hline Osteocalcin & & 184 & 30 \\
\hline forward & 5'-GGGCAATAAGGTAGTGAACAG-3' & & \\
\hline reverse & 5'-GCAGCACAGGTCCTAAATAGT-3' & & \\
\hline Drg-1 & & 433 & 31 \\
\hline forward & 5'-CGCTGAGGTGAAGCCTCTGGTG-3' & & \\
\hline reverse & 5'-AGGGTTGTTGAGTGCGAAGCGG-3' & & \\
\hline$\beta$-actin & & 275 & 22 \\
\hline forward & 5'-CAGGAGATGGCCACTGCCGCA-3' & & \\
\hline reverse & 5'-AGGGTTGTTGAGTGCGAAGCGG-3' & & \\
\hline
\end{tabular}


bromide staining. The experiment was performed using three independent RNA samples for each treatment.

\section{Statistical analyses}

Significant differences among multiple independent groups were statistically evaluated using one-way ANOVA and subsequent comparisons were made with the TukeyKramer test. Significant differences between 2 independent groups were analyzed with Student's $t$-test. For all statistical analyses, the criterion for significance was $\mathrm{p}<0.05$.

\section{Competing interests}

The authors declare that they have no competing interests.

\section{Authors' contributions}

AN participated in the design, and performed the bulk of experiments. JA participated in the proliferation, invasion, and migration assays. KS and TK participated in the experimental design, coordination and the corrections of the manuscript. TT participated in the RT-PCR experiments. YN participated in the immunohistochemical experiments. $\mathrm{HM}$ ( $\mathrm{H}$. Miura) participated in the experimental design, coordination and the corrections of the manuscript. HM (H. Masuno) was responsible for the experimental design, statistical analysis of the data, drafting of the manuscript and conceiving this study. All authors read and approved the final manuscript.

\section{Acknowledgements}

This work was supported in part by a grant (kyouiku Kenkyu Joseihi) from Ehime Prefectural University of Health Sciences (H. Masuno).

\section{Author details}

'Department of Bone and Joint Surgery, Ehime University Graduate School of Medicine, Toon, Ehime 791-0295, Japan. ${ }^{2}$ Department of Medical Technology, Faculty of Health Sciences, Ehime Prefectural University of Health Sciences, Takooda, Tobe-cho, lyo-gun, Ehime, 791-2101, Japan. ${ }^{3}$ Musculoskeletal Tumor Surgery Center, Minami Matsuyama Hospital, Matsuyama, Ehime 790-8534, Japan.

Received: 13 June 2012 Accepted: 20 September 2012 Published: 26 September 2012

\section{References}

1. Dome JS, Schwartz CL: Osteosarcoma. Cancer Treat Res 1997, 92:215-251.

2. Bacci G, Longhi A, Versari M, Mercuri M, Briccoli A, Picci P: Prognostic factors for osteosarcoma of the extremity treated with neoadjuvant chemotherapy: 15-year experience in 789 patients treated at a single institution. Cancer 2006, 106:1154-1161.

3. Ferguson WS, Goorin AM: Current treatment of osteosarcoma. Cancer Invest 2001, 19:292-315.

4. Saeter G, Høie J, Stenwig AE, Johansson AK, Hannisdal E, Solheim OP: Systemic relapse of patients with osteogenic sarcoma: Prognostic factors for long term survival. Cancer 1995, 75:1084-1093.

5. Bacci G, Briccoli A, Ferrari S, Saeter G, Donati D, Longhi A, Manfrini M, Bertoni F, Rimondini S, Monti C, Forni C: Neoadjuvant chemotherapy for osteosarcoma of the extremities with synchronous lung metastases: treatment with cisplatin, adriamycin and high dose of methotrexate and ifosfamide. Oncol Rep 2000, 7:339-346.

6. Asai T, Ueda T, Itoh K, Yoshioka K, Aoki Y, Mori S, Yoshikawa H: Establishment and characterization of a murine osteosarcoma cell line (LM8) with high metastatic potential to the lung. Int J Cancer 1998, 76:418-422.

7. Kamei S, Sakayama K, Tamashiro S, Aizawa J, Miyawaki J, Miyazaki T, Yamamoto H, Norimatsu Y, Masuno H: Ketoprofen in topical formulation decreases the matrix metalloproteinase-2 expression and pulmonary metastatic incidence in nude mice with osteosarcoma. J Orthop Res 2009, 27:909-915

8. Aizawa J, Sakayama K, Kamei S, Kidani T, Yamamoto H, Norimatsu Y, Masuno $\mathrm{H}$ : Effect of troglitazone on tumor growth and pulmonary metastasis development of the mouse osteosarcoma cell line LM8. BMC Cancer 2010, 10:51.

9. Stetler-Stevenson WG, Aznavoorian S, Liotta LA: Tumor cell interactions with the extracellular matrix during invasion and metastasis. Annu Rev Cell Biol 1993, 9:541-573.

10. Kaya M, Wada T, Akatsuka T, Kawaguchi S, Nagoya S, Shindoh M, Higashino F, Mezawa F, Okada F, Ishii S: Vascular endothelial growth factor expression in untreated osteosarcoma is predictive of pulmonary metastasis and poor prognosis. Clin Cancer Res 2000, 6:572-577.

11. Yamamoto S, Sobue T, Kobayashi M, Sasaki S, Tsugane S: Soy, isoflavones, and breast cancer risk in Japan. J Natl Cancer Inst 2003, 95:906-913.

12. Record IR, Broadbent JL, King RA, Dreosti IE, Head RJ, Tonkin AL: Genistein inhibits growth of B16 melanoma cells in vivo and in vitro and promotes differentiation in vitro. Int J Cancer 1997, 72:860-864.

13. Morris C, Thorpe J, Ambrosio L, Santin M: The soybean isoflavone genistein induces differentiation of MG63 human osteosarcoma osteoblasts. J Nutr 2006, 136:1166-1170.

14. Singh AV, Franke AA, Blackburn GL, Zhou J-R: Soy phytochemicals prevent orthotopic growth and metastasis of bladder cancer in mice by alterations of cancer cell proliferation and apoptosis and tumor angiogenesis. Cancer Res 2006, 66:1851-1858.

15. Lin S-Y, Xia W, Wang JC, Kwong KY, Spohn B, Wen Y, Pestell RG, Hung MC: $\beta$-Catenin, a novel prognostic marker for breast cancer: Its roles in cyclin D1 expression and cancer progression. Proc Natl Acad Sci USA 2000, 97:4262-4266.

16. Iwaya K, Ogawa H, Kuroda M, Izumi M, Ishida T, Mukai K: Cytoplasmic and/ or nuclear staining of beta-catenin is associated with lung metastasis. Clin Exp Metastasis 2003, 20:525-529.

17. Yoshizumi T, Ohta T, Ninomiya I, Terada I, Fushida S, Fujimura T, Nishimura G, Shimizu K, Yi S, Miwa K: Thiazolidinedione, a peroxisome proliferatoractivated receptor- $\gamma$ ligand, inhibits growth and metastasis of HT-29 human colon cancer cells through differentiation-promoting effects. Int $J$ Oncol 2004, 25:631-639.

18. Aronow MA, Gerstenfeld LC, Owen TA, Tassinari MS, Stein GS, Lian JB: Factors that promote progressive development of the osteoblast phenotype in cultured fetal rat calvaria cells. J Cell Physiol 1990, 143:213-221.

19. van Belzen N, Dinjens WN, Diesveld MP, Groen NA, van der Made AC, Nozawa $Y$, Vlietstra R, Trapman J, Bosman FT: A novel gene which is up-regulated during colon epithelial cell differentiation and down-regulated in colorectal neoplasms. Lab Invest 1997, 77:85-92.

20. Harmon AW, Harp JB: Differential effects of flavonoids on 3T3-L1 adipogenesis and lipolysis. Am J Physiol Cell Physiol 2001, 280:C807-C813.

21. Sandoval MJ, Cutini PH, Rauschemberger MB, Massheimer VL: The soyabean isoflavone genistein modulates endothelial cell behaviour. $\mathrm{Br} J$ Nutr 2010, 104:171-179.

22. Kashima T, Kawaguchi J, Takeshita S, Kuroda M, Takanashi M, Horiuchi H, Imamura T, Ishikawa Y, Ishida T, Mori S, Machinami R, Kudo A: Anomalous cadherin expression in osteosarcoma. Possible relationships to metastasis and morphogenesis. Am J Pathol 1999, 155:1549-1555.

23. Hugh TJ, Dillon SA, O'Dowd G, Getty B, Pignatelli M, Poston GJ, Kinsella AR: $\beta$-Catenin expression in primary and metastatic colorectal carcinoma. Int J Cancer 1999, 82:504-511.

24. Su Y, Simmen RCM: Soy isoflavone genistein upregulates epithelial adhesion molecule E-cadherin expression and attenuates $\beta$-catenin signaling in mammary epithelial cells. Carcinogenesis 2009, 30:331-339.

25. Su Y, Simmen FA, Xiao R, Simmen RCM: Expression profiling of rat mammary epithelial cells reveals candidate signaling pathways in dietary protection from mammary tumors. Physiol Genomics 2007, 30:8-16.

26. He TC, Sparks AB, Rago C, Hermeking H, Zawel L, da Costa LT, Morin PJ, Vogelstein B, Kinzler KW: Identification of c-MYC as a target of the APC pathway. Science 1998, 281:1509-1512.

27. Miyazawa K, Iwaya K, Kuroda M, Harada M, Serizawa H, Koyanagi Y, Sato Y, Mizokami Y, Matsuoka T, Mukai K: Nuclear accumulation of beta-catenin in intestinal-type gastric carcinoma: correlation with early tumor invasion. Virchows Arch 2000, 437:508-513.

28. Abercrombie M: Contact inhibition and malignancy. Nature 1979, 281:259-262. 
29. Kurdistani SK, Arizti P, Reimer CL, Sugrue MM, Aaronson SA, Lee SW: Inhibition of tumor cell growth by RTP/rit42 and its responsiveness to p53 and DNA damage. Cancer Res 1998, 58:4439-4444.

30. Guan RJ, Ford HL, Fu Y, Li Y, Shaw LM, Pardee AB: Drg-1 as a differentiation-related, putative metastatic suppressor gene in human colon cancer. Cancer Res 2000, 60:749-755.

31. Chua M-S, Sun H, Cheung ST, Mason V, Higgins J, Ross DT, Fan ST, So S: Overexpression of NDRG1 is an indicator of poor prognosis in hepatocellular carcinoma. Mod Pathol 2007, 20:76-83.

32. Bandyopadhyay $S$, Wang $Y$, Zhan R, Pai SK, Watabe M, liizumi M, Furuta E, Mohinta S, Liu W, Hirota S, Hosobe S, Tsukada T, Miura K, Takano Y, Saito K, Commes T, Piquemal D, Hai T, Watabe $K$ : The tumor metastasis suppressor gene $\mathrm{Drg}-1$ down-regulates the expression of activating transcription factor 3 in prostate cancer. Cancer Res 2006, 66:11983-11990.

33. Matsugaki T, Zenmyo M, Hiraoka K, Fukushima N, Shoda T, Komiya S, Ono M, Kuwano M, Nagata K: N-myc downstream-regulated gene 1/Cap43 expression promotes cell differentiation of human osteosarcoma cells. Oncol Rep 2010, 24:721-725.

34. Wu AH, Wan P, Hankin J, Tseng C-C, Yu MC, Pike MC: Adolescent and adult soy intake and risk of breast cancer in Asian-Americans. Carcinogenesis 2002, 23:1491-1496.

35. Horn-Ross PL, John EM, Lee M, Stewart SL, Koo J, Sakoda LC, Shiau AC, Goldstein J, Davis P, Perez-Stable EJ: Phytoestrogen consumption and breast cancer risk in a multiethnic population: The Bay Area breast cancer study. Am J Epidemiol 2001, 154:434-441.

36. Lakshman M, Xu L, Ananthanarayanan V, Cooper J, Takimoto CH, Helenowski I, Pelling JC, Bergan RC: Dietary genistein inhibits metastasis of human prostate cancer in mice. Cancer Res 2008, 68:2024-2032.

37. Hinegardner RT: An improved fluorometric assay for DNA. Anal Biochem 1971, 39:197-201.

38. Zamurovic N, Cappellen D, Rohner D, Susa M: Coordinated activation of Notch, Wnt, and transforming growth factor- $\beta$ signaling pathways in bone morphogenic protein 2-induced osteogenesis. J Biol Chem 2004, 279:37704-37715.

39. Song C, Guo Z, Ma Q, Chen Z, Liu Z, Jia H, Dang G: Simvastatin induces osteoblastic differentiation and inhibits adipocytic differentiation in mouse bone marrow stromal cells. Biochem Biophys Res Commun 2003, 308:458-462.

doi:10.1186/1471-2121-13-24

Cite this article as: Nakamura et al:: Genistein inhibits cell invasion and motility by inducing cell differentiation in murine osteosarcoma cell line LM8. BMC Cell Biology 2012 13:24.

\section{Submit your next manuscript to BioMed Central and take full advantage of:}

- Convenient online submission

- Thorough peer review

- No space constraints or color figure charges

- Immediate publication on acceptance

- Inclusion in PubMed, CAS, Scopus and Google Scholar

- Research which is freely available for redistribution 